\title{
DA (IM)POSSIBILIDADE DE UM TRATAMENTO PRINCIPIOLÓGICO DO ENRIQUECIMENTO SEM CAUSA NO BRASIL
}

\author{
THE (IM)POSSIBILITY OF A PRINCIPOLOGIC APPROACH OF UNJUSTIFIED \\ ENRICHMENT IN BRAZIL
}

\author{
Sabrina Jiukoski da Silva \\ Mestre em Direito (UFSC) \\ Universidade Federal de Santa Catarina \\ Florianópolis /SC. Brasil \\ sjiukoski@gmail.com \\ Alexandre Morais da Rosa \\ Doutor em Direito (UFPR) \\ Universidade Federal de Santa Catarina \\ Florianópolis /SC. Brasil \\ alexandremoraisdarosa@gmail.com
}

Resumo: O presente artigo objetiva aclarar o tratamento assistemático dado ao enriquecimento em causa na prática forense, que é, por vezes, invocado como princípio capaz de traçar critérios de justiça e equidade. A partir do método dedutivo, para tanto, traçar-se-á a análise a partir da consolidação do enriquecimento sem causa e seus elementos estruturais no Brasil até a sua reconstrução histórica, afastando-se, ao final, a aplicação principiológica do enriquecimento sem causa, pois é um ramo do direito das obrigações alicerçado na abstração de causa.

Palavras-chave: Direito Civil. Obrigações. Enriquecimento sem causa.

Abstract: This article has as objective to verify unsystematic approach of unjustified enrichment in the national courts, that is brought sometimes as a principle capable of drawing justice and equity criteria. Based on a deductive method, it will be made the analysis from the unjustified enrichment consolidation and its structure in Brazil to its historical evolution, moving away from the principologic application of the unjustified enrichment in the conclusion, because it is part of law of obligation based on cause abstraction.

Keywords: Civil law. Obligations. Unjustified enrichment.

Para citar este artigo (ABNT NBR 6023:2018)

SILVA Sabrina Jiukoski da; ROSA, Alexandre Morais da. Da (im)possibilidade de um tratamento principiológico do enriquecimento sem causa no Brasil. Revista Thesis Juris - RTJ, São Paulo, v. 9, n. 2, p. 258-280, jul./dez. 2020. http://doi.org/10.5585/rtj.v9i2.17219. 


\section{Introdução}

Presente em diversas decisões dos tribunais nacionais, a expressão "sob pena de enriquecimento sem causa" é empregada no sentido de constituir a figura do enriquecimento sem causa como um princípio implícito à ordem jurídica. Fala-se, pois, em enriquecimento sem causa como critério limitativo para o arbitramento dos danos extrapatrimoniais, como fundamento para a caracterização do dever de indenizar os danos materiais no caso do uso indevido da imagem ou do nome alheio, como parâmetro avaliativo, valorativo ou até mesmo resolutivo de diversas relações negociais etc. Além disso, a expressão é comumente aplicada em outros ramos do Direito, que não o privado, como ocorre no direito público, trabalhista etc.

Como evidencia Konder (2005, p. 371-372), em diversas ocasiões um princípio do enriquecimento sem causa é invocado no âmbito de aplicação de uma norma que atribua ao magistrado um grau maior de discricionariedade e, em outras, aparece como ratio decidendi diante da obscuridade ou lacunas da lei. Mas, outras tantas vezes, o princípio é invocado como uma espécie de 'válvula de escape' interna ao sistema, para situações nas quais a aplicação excessivamente rígida da legislação levaria a situações injustas.

Nanni (2004, p. 187) também reconhece o uso discricionário do princípio ao ponderar que "os operadores do direito fazem uso do enriquecimento sem causa, em variadas circunstâncias, sem associá-lo à ação de enriquecimento, mas sim buscando conferir à hipótese concreta um critério de justiça e razoabilidade".

Guia Silva, mais recentemente, também evidencia essa invocação indiscriminada de um princípio de vedação ao enriquecimento sem causa na prática forense. Segundo o autor, esta invocação ocorre como "panaceia de todos os problemas, sem maior esforço de depuração do conteúdo de tal princípio e sem atenção detida às potencialidades do instituto da vedação ao enriquecimento sem causa" (GUIA SILVA, 2020b).

Mas essa invocação, aparentemente simplista, traz consigo um importante questionamento para a compreensão das potencialidades, das limitações e do emprego do enriquecimento sem causa no direito nacional: o enriquecimento sem causa se constitui princípio implícito à ordem jurídica ou é figura institucional de caráter concreto?

Buscando respostas à tal problemática, o presente estudo, a partir do raciocínio dedutivo, centra seus esforços em verificar se o tratamento principiológico dado ao enriquecimento sem causa guarda real coerência sistemática. O intuito é, pois, compreender o fundamento e os elementos estruturais próprios do enriquecimento sem causa e assim verificar se essa noção principiológica se coaduna com a sua moderna teoria. 
Para tanto, a primeira seção demonstrará as linhas gerais sobre a consolidação do enriquecimento sem causa no ordenamento jurídico brasileiro; a segunda seção cuidará dos requisitos clássicos e estruturais do enriquecimento sem causa na doutrina e na jurisprudência nacionais; e a terceira seção tratará diretamente do objetivo do presente artigo, a partir do estudo das raízes romanas até o desenvolvimento moderno da figura do enriquecimento sem causa em terras germânicas, grande influenciadora do direito restituitório nacional. Por fim, serão traçadas as considerações finais e conclusivas.

\section{Breves considerações sobre a consolidação do enriquecimento sem causa no direito brasileiro}

Diante da opção legislativa de não positivar uma cláusula geral de vedação ao enriquecimento sem causa no Código Civil de 1916, a construção da figura do enriquecimento sem causa no direito brasileiro ocorreu através dos poucos estudos doutrinários dedicados à temática na época e de uma lenta construção jurisprudencial baseada na casuística.

Clóvis Beviláqua (1977, p. 115-118), autor do anteprojeto que originou a codificação, apesar de reconhecer a existência de um dever de restituir a partir do locupletamento à custa alheia, entendia não ser necessária a positivação de uma cláusula geral para compreender todas as situações que se configuram como enriquecimento sem causa, mas tão somente de alguns casos específicos, dado que os demais deveriam ser resolvidos a partir do direito e da equidade, restabelecendo o equilíbrio dos interesses e dando satisfação aos reclamos ${ }^{1}$.

Tal posição refletiu na positivação de alguns casos específicos que envolviam o locupletamento à custa alheia no Código Civil de 1916, deixando de lado a consolidação de uma cláusula geral de vedação ao enriquecimento sem causa no Brasil².

Conquanto a opção legislativa, pouco a pouco casos envolvendo o enriquecimento às custas de outrem não positivados na codificação chegaram aos tribunais, e doutrina ${ }^{3}$ e jurisprudência voltavam-se às noções de justiça e equidade e aos velhos brocados do Direito

\footnotetext{
${ }^{1}$ Nas palavras do autor, "o que se locupleta com o alheio, está na posição do que toma alguma coisa por empréstimo: tem de restituí-la", mas "não se póde, numa formula geral, compreender todos os casos de enriquecimento antijurídico", dado que "por mais que variemos as hyotheses, veremos que o direito e equidade se pódem plenamente satisfazer, sem crearmos, nos Códigos Civis, mais esta figura de causa gerado de obrigação, ou seja uma relação obrigacional abstracta e genérica" (BEVILÁQUA, 1977, p. 112, 114 e 1118).

${ }^{2}$ Noronha ensina que a codificação apenas apresentava dispositivos que podem ser considerados aplicações fracionárias de um princípio de vedação ao enriquecimento sem causa. O CC/1916 reconhecia nos artigos 157 e 936 as regras da não validade de pagamentos efetuados a incapazes, salvo se quem paga provar que a importância entre reverteu em proveito de quem recebeu. Os artigos 510 a 519 regulavam os frutos, benfeitorias e deteriorações. Os artigos 536 a 549 tratavam sobre a aquisição por acessão (NORONHA, 1991, p. 52-55). Entre outras disposições, o Código também tratou de matérias próximas às raízes do enriquecimento sem causa, como a gestão de negócios (arts. 1331 a 1345) e o pagamento indevido (arts. 964 a 971).

${ }^{3}$ Ensina Nanni que "o instituto permaneceu relegado pela maior parte da doutrina, recebendo, em regra, pequenas menções do nos estudos jurídicos” (NANNI, 2004, p. 93). Agostinho Alvim (1957, p. 12), por sua vez, sustenta que a ausência do texto legal, para alguns, motivou a negação da possibilidade de um direito restituitório e, para outros, o simples fato do legislador não reconhecer o instituto, fechou a porta ao enriquecimento sem causa.
} 
Romano para justificar a existência de um princípio geral de vedação ao enriquecimento sem causa no sistema jurídico brasileiro (NORONHA, 1991, p. 56).

Agostinho Alvim entendia ser "inquestionável que a condenação do enriquecimento injustificado é princípio geral de Direito, porque, com maior ou menor extensão, ela tem sido recomendada por todos os sistemas, no tempo e no espaço", e defendia que "no silêncio da lei não podemos favorecer o enriquecimento sem justificativa, e isso por uma série de motivos, com base no nosso sistema e nos princípios cardiais do direito universal, que vêm orientando [...] as legislações dos povos cultos" (ALVIM, 1957, p. 14 e 18).

No mesmo sentido, Orlando Gomes considerava que a lacuna legislativa não poderia ser interpretada no sentido de excluir a existência de um princípio segundo o qual deve-se restituir a vantagem patrimonial obtida injustamente (GOMES, 1998, p. 302), e Silvio Rodrigues considerava que o princípio genérico de vedação ao enriquecimento sem causa tem como base o princípio maior da equidade, o qual proíbe o ganho de um em detrimento de outro, sem causa que o justifique (RODRIGUES, 1996, p. 159).

Nesse contexto, as primeiras decisões dos tribunais nacionais envolvendo o tema sustentavam o dever de restituir a partir da primeira máxima de Pompônio contida no Digesto Justiniano $(50,17,206)$ : “jure naturae aequum est neminem cum alterius detrimento et injuria fieri locupletiorem", e consagravam o enriquecimento sem causa como princípio implícito ao sistema normativo $^{5}$, mas sem uniformizar critérios de sua aplicação (PAES, 1975, p. 164 e 167).

Percebendo a imprecisão da figura do enriquecimento sem causa na jurisprudência ${ }^{6}$, em meados do século, a doutrina, ainda que defendendo a existência de um princípio geral do Direito, passou a forjar regras impeditivas de enriquecimento sem causa a partir do estudo de outras realidades jurídicas, em especial as diretrizes francesas e germânicas, identificando os elementos indispensáveis para a caracterização do dever de restituir e defendendo a positivação de uma cláusula geral na legislação civil, enquanto figura geradora de obrigações ${ }^{7}$.

Nas palavras de Valle Ferreira (1949, p. 55):

\footnotetext{
4 Tradução livre: "é justo, por direito natural, que ninguém se enriqueça em detrimento ou em prejuízo de outro".

${ }^{5}$ Sobre o assunto, Guia Silva disserta que "Vislumbrava-se tal formulação como a resposta necessária às eventuais lacunas da legislação, sobretudo quando o recurso à analogia legis se revelasse insuficiente para a resolução de algum litígio. Desse modo, a vedação ao enriquecimento sem causa deveria ser levada em consideração pelo intérprete diante de lacuna da lei, em atuação integradora característica dos princípios gerais do Direito, conforme previsão do artigo $7^{\circ}$ da Introdução ao Código Civil de 191617 e do artigo $4^{\circ}$ da Lei de Introdução às Normas de Direito Brasileiro (denominação atual do Decreto-Lei nº 4.657/1942).” (GUIA SILVA, 2019a, p. 125).

${ }^{6} \mathrm{Na}$ perspectiva de Negreiros, "parte desta falta de uniformidade traduz-se na própria conceituação do enriquecimento sem causa como princípio geral de direito. Com efeito, hoje, a doutrina predominante sinaliza no sentido de reconhecer no direito positivo brasileiro manifestações concretas do acolhimento da teoria do enriquecimento sem causa que justificaria a sua qualificação como um princípio do ordenamento civilista" (NEGREIROS, 2002, p. 759).

${ }^{7}$ Ensina Negreiros (2002, p. 780-784) que doutrinadores, como Carvalho de Mendonça e Jorge Americano, defendiam a posição de Clóvis Beviláqua e, embora não negassem a existência de um princípio de vedação ao enriquecimento sem causa, não o reconheciam como um instituto autônomo.
} 
[...] o princípio que fulmina o enriquecimento sem causa foi elaborado pela jurisprudência e entrou na vida jurídica e dela se impregnou, já é tempo de admitirmos uma construção dogmática, de linhas nítidas e em termos jurídicos. Transformaríamos, assim, a ação de enriquecimento sem causa - de simples corretivo do direito escrito em realidade vida, em instituto autônomo, para que pudesse operar sob determinadas condições e em círculo definido, de modo a remover, na prática, o perigo das decisões de arbítrio.

De forma similar, Agostinho Alvim (1957, p. 18), Pontes de Miranda (1959, p. 164165), Orozimbo Nonato (1960, p. 84-88) e Pedro Paes (1975, p. 240) defendiam a impossibilidade de um tratamento meramente casuísta ao enriquecimento sem causa ${ }^{8}$ e enumeraram, ainda que sem perfeita uniformidade de opiniões, os requisitos indispensáveis ao exercício da ação de enriquecimento: (i) enriquecimento; (ii) empobrecimento; (iii) nexo de causalidade entre estes; e (iv) ausência de justa causa ou de título jurídico 9 .

Não demorou muito e a jurisprudência nacional passou a cristalizar tais elementos como indispensáveis para a configuração da ação de enriquecimento sem causa (PAES, 1975, p. 167) e, mais do que isso, ainda na vigência do Código Civil de 1916, o Superior Tribunal de Justiça, através do voto da lavra do então ministro Waldemar Zveiter no recurso especial. n. 11025/SP, reconheceu a autonomia da figura do enriquecimento sem causa, como fonte especial do Direito Obrigacional, sob o fundamento de que "o simples fato de um deslocamento de uma parcela patrimonial de um núcleo que se empobrece para incrementar o outro que se enriquece é o bastante para criar efeitos obrigacionais" (BRASIL, 1991).

A par dessas considerações, doutrina e jurisprudência passaram a reconhecer o enriquecimento sem causa como uma figura institucional de caráter concreto e a positivação de uma regra geral contemplando a proibição do enriquecimento sem causa ingressou definitivamente na pauta de reforma da legislação civil.

Agostinho Alvim, responsável pela elaboração do título que contemplava o Direito Obrigacional, além de consagrar uma cláusula geral, dedicou um capítulo da nova codificação ao enriquecimento sem causa, regrando-o em três artigos (884, 885 e 886), todos inseridos atualmente no Capítulo IV, denominado "Do Enriquecimento Sem Causa”, no Título VII (Dos Atos Unilaterais), do Livro I (Do Direito das Obrigações), da Parte Especial ${ }^{10}$ :

\footnotetext{
${ }^{8}$ É possível identificar outras críticas doutrinária, para maiores detalhes, ler: NANNI, 2004, p. 86 e ss.

${ }^{9}$ Agostinho Alvim (1957, p. 18) ensina que: “Alguns autores são mais sintéticos, por entenderem que estes ou aqueles requisitos não merecem destaque, visto já se acharem compreendidos em outra categoria. O requisito relativo ao caráter subsidiário da ação é bastante discutido. Ocorre, ainda, que algum requisito merece contemplado por dizer respeito à quase totalidade dos casos; mas não se poderia considerar como essencial, ou elementar, visto dele se poder prescindo em algumas hipóteses especiais.".

${ }^{10}$ Como lembra Konder (2005, p. 381), não só o anteprojeto de 1975, mas também os anteriores (1941 e 1965) trouxeram o instituto em seu bojo.
} 
Art. 884. Aquele que, sem justa causa, se enriquecer à custa de outrem, será obrigado a restituir o indevidamente auferido, feita a atualização dos valores monetários.

Parágrafo único. Se o enriquecimento tiver por objeto coisa determinada, quem a recebeu é obrigado a restituí-la, e, se a coisa não mais subsistir, a restituição se fará pelo valor do bem na época em que foi exigido.

Art. 885. A restituição é devida, não só quando não tenha havido causa que justifique o enriquecimento, mas também se esta deixou de existir.

Art. 886. Não caberá a restituição por enriquecimento, se a lei conferir ao lesado outros meios para se ressarcir do prejuízo sofrido ${ }^{11}$.

Como corolário lógico, com a promulgação do novo Código Civil, por meio da lei $\mathrm{n}^{\mathrm{o}}$ 10.406 de 10 janeiro de 2002, consolida-se a autonomia do enriquecimento sem causa no direito brasileiro, como fonte de obrigações ao lado das obrigações negociais e de responsabilidade civil, o que, nas palavras de Nanni (2004, p. 97), representou verdadeira "conquista daqueles que sempre o defenderam como um instituto autônomo no direito obrigacional"12.

De modo a contribuir para o entendimento da funcionalidade e da estruturação do enriquecimento em causa no Direito Civil, passa-se a analisar no próximo tópico os requisitos clássicos ${ }^{13}$ que compõem o instituto no direito brasileiro.

\section{Os requisitos da pretensão ao enriquecimento sem causa}

O desenvolvimento conferido pela doutrina nacional à figura do enriquecimento sem causa, durante a tramitação do Código Civil de 2002, definiu os pressupostos clássicos e constitutivos deste dever de restituir no Brasil: (i) enriquecimento; (ii) empobrecimento; (iii) nexo de causalidade entre estes; e (iv) ausência de justa causa ou de título jurídico.

Entre os citados requisitos, os dois primeiros, durante quase uma década, foram objeto de discussão doutrinária, diante da leitura e da interpretação dada à locução "enriquecer à custa de outrem" constante no caput do artigo 884 do Código Civil de 2002. A necessidade da comprovação do primeiro requisito (enriquecimento) sempre foi unânime na doutrina, mas existia a divergência no conceito e na abrangência do termo no direito nacional, dado que, embora pareça simples em uma interpretação literal, o conceito de enriquecimento não é meramente fático, mas também normativo. Por outro lado, o segundo requisito

\footnotetext{
${ }^{11}$ O Código manteve a regulação anterior no que tange ao pagamento indevido e a gestão de negócios. Ainda, as situações específicas de enriquecimento sem causa como, por exemplo, os frutos e as despesas do possuidor, de boa ou má-fé (art. 1214 e ss. do Código Civil de 2002).

${ }^{12}$ É importante destacar, nesse ponto, as conclusões de Guia Silva (2019a, p. 145-146; 2019b, 10-11), as quais se corroboram neste artigo. Quer dizer, não se pode esquecer que o enriquecimento sem causa é fonte de obrigações e assim a cláusula geral (art. 884) é apenas uma das diversas manifestações da fonte obrigacional da vedação ao enriquecimento sem causa, pois "[...] a fonte obrigacional da vedação ao enriquecimento sem causa manifesta-se, no Direito positivo brasileiro, tanto pela cláusula geral do dever de restituir prevista pelo artigo 884 do Código Civil quanto por previsões legais específicas de restituição que ostentem a função restitutória. O regime da vedação ao enriquecimento sem causa não se esgota, portanto, na cláusula geral do dever de restituir, tal como o regime da responsabilidade civil certamente não se esgota nas cláusulas gerais do dever de indenizar previstas pelos artigos 186 e 927, caput e parágrafo único, do Código Civil." (GUIA SILVA, 2019a)

${ }^{13}$ Fala-se clássico, pois contemplados pela maior parte da doutrina civilista nos ordenamentos de tradição jurídica romano-germânica e, atualmente, amplamente aceitos do direito nacional.
} 
(empobrecimento) encontrava grande divergência, tanto que muitos doutrinadores optaram por não utilizar o termo empobrecimento, referindo-se, em seu lugar, à necessidade de que o enriquecimento ocorra "às custas de outrem" (KONDER, 2005, p. 383).

Entre os primeiros escritos, alguns doutrinadores defendiam que o "fato gerador da reparação por restituição do indevido, em todo o momento, apresentou coligação do enriquecimento com o empobrecimento" (PAES, 1975, p. 106) ${ }^{14}$. Não havia, pois, como falar em enriquecimento sem causa sem o correspondente empobrecimento de uma das partes. A título de exemplo, se uma pessoa utilizasse a casa de veraneio alheia sem qualquer autorização do proprietário, segundo essa posição doutrinária, mesmo que o agente tenha enriquecido, poupando o aluguel do imóvel durante sua permanência, não haveria o dever de restituir, pois, em princípio, não houve um efetivo empobrecimento do proprietário.

Contudo, pouco a pouco a doutrina passou a superar esta correlação entre enriquecimento e empobrecimento. Como ensina Pedro Paes (1975, p. 111), a doutrina passou a defender a desnecessidade de que o bem enriquecedor tenha como origem o patrimônio do empobrecido no sentido de transferência patrimonial ou efetivo empobrecimento, bastando que haja a conjectura, o vislumbre da integração patrimonial. Significa dizer que, ainda na vigência do Código de Beviláqua, a melhor doutrina passou a defender que basta para o instituto do enriquecimento sem causa que o enriquecimento derive direita ou indiretamente do patrimônio da pessoa empobrecida (do titular do direito), inexistindo a necessidade de um efetivo empobrecimento através de uma translação patrimonial.

Agostinho Alvim (1957, p. 19-20) disserta que o enriquecimento deve ser tomado em sentido amplo, compreendendo "qualquer aumento do patrimônio, ou diminuição evitada, e até vantagens não patrimoniais, desde que estimáveis em dinheiro" "15, e o empobrecimento, por sua vez, pode consistir "numa diminuição efetiva do patrimônio ou, no fato de ter sido impedido o seu aumento, em simetria com o dano emergente e o lucro cessante".

Pontes de Miranda (1959, p. 164-168) conceitua o enriquecimento como a obtenção de algo, um acréscimo no patrimônio do sujeito passivo da relação jurídica restituitória, descontando-se, em análise ao caso concreto, eventuais despesas em que o enriquecido tenha incorrido em razão do acréscimo patrimonial. São exemplos de enriquecimento, para o autor, a

\footnotetext{
${ }^{14} \mathrm{O}$ entendimento baseava-se a tradicional doutrina francesa e a escola pandectista que, segundo Nanni (2004, p. 246), defendem que “para exercitar-se a ação de enriquecimento é preciso que tenha ocorrido a transferência patrimonial de bens do empobrecido para o enriquecido, de tal sorte que um aumente e o outro diminua".

${ }^{15} \mathrm{O}$ autor complementa "poderá consistir, e é o mais frequente, na deslocação de um valor, de um para outro patrimônio; num dano evitado; na inutilização da coisa própria; numa diminuição de despesa; na transmissão da posse (condictio possessionis); numa remissão de dívida; em serviços prestados; em algum benefício moral com valor pecuniário; enfim, na incorporação ao patrimônio de um elemento material ou imaterial." (ALVIM, 1957., p. 19). Orozimbo Nonato e Valle Ferreira tratam dos pressupostos do enriquecimento e do empobrecimento à semelhança de Agostinho Alvim (FERREIRA, 1949, p. 130 e ss. e NONATO, 1960, p. 105 e ss.).
} 
aquisição de direito, pretensão, ação ou exceção, a obtenção da posse, a obtenção da possibilidade de disposição do bem, o evitar ou o poder evitar despesas indispensáveis, a economia de trabalho próprio, o uso ou consumo de coisas alheias etc. Mas sempre é preciso que o enriquecimento de alguém corresponda a desvantagem de outrem. E essa desvantagem, disserta Pontes de Miranda, pode ser algo que se perdeu, uma prestação de uma pessoa para outra ou algo que o titular do direito teria adquirido se não tivesse ocorrido o enriquecimento ${ }^{16}$.

Noronha (1991, p. 59 e 65), por sua vez, dispõe que o enriquecimento é um acréscimo ou ganho efetivo do patrimônio e o empobrecimento não deve estar correlacionado somente a um "dano" - a um resultado negativo no patrimônio -. Para além desse dano, o autor entende pelo emprego da locução "à custa de outrem", que deve ser interpretada como "todo o enriquecimento conseguido com bens jurídicos de outra pessoa, mesmo que esta não sofra qualquer dano". Isso porque tanto pode existir um enriquecimento a partir de uma transferência patrimonial propriamente dita, sendo que uma das parte sofre um verdadeiro empobrecimento, na medida em que o seu patrimônio fica diminuído com a saída do bem, quanto um enriquecimento a partir da exploração de coisas, trabalho e outros direitos alheios, tendo uma das partes se apropriado de um valor que não estava no patrimônio do prejudicado, mas cuja realização estava tão somente a este reservada (NORONHA, 1991, p. 66).

Após a entrada em vigor do Código Civil de 2002, com o objetivo de debater sobre as novas disposições legislativas, os doutrinadores civilistas se reuniram na I Jornada de Direito Civil, realizada pelo Conselho da Justiça Federal. Na ocasião, no âmbito do instituto do enriquecimento sem causa, restou aprovado o enunciado $\mathrm{n}^{\mathrm{o}} 35$ com a seguinte redação: “A expressão 'se enriquecer à custa de outrem' do art. 884 do novo Código Civil não significa, necessariamente, que deverá haver empobrecimento" (BRASIL, 2002). De modo que, por unanimidade, a expressão empobrecimento foi substituída pela locação "à custa de outrem" e o entendimento firmou-se no sentido de que o enriquecimento pode ocorrer tanto a partir de uma efetiva transferência patrimonial, originando um empobrecimento de uma das partes, como também a partir do direito subjetivo de outrem, respeitando a distribuição natural das riquezas.

É nesse sentido o posicionamento de Nanni (2004, p. 226-228 e 245-250), segundo o qual, na acepção do direito brasileiro, o enriquecimento deve ser entendido em sentido amplo, trata-se de um conceito elástico, indeterminado e correlacionado às circunstâncias do caso concreto. Por outro lado, o Código Civil de 2002 não situa o empobrecimento propriamente dito como um requisito específico para a configuração da obrigação de enriquecimento sem

\footnotetext{
${ }^{16}$ Destaca-se que o autor não utiliza como pressuposto da obrigação de enriquecimento sem causa a expressão "empobrecimento", tratando apenas de "enriquecimento a expensas de outrem".
} 
causa, devendo a expressão "à custa de outrem", tal qual disposta no caput do artigo 884, ser interpretada como à obtenção de uma vantagem econômica a partir de outro patrimônio.

Maria Candida Kroetz (2005, p. 385-388) afirma que nem sempre o enriquecimento obtido é equivalente ao empobrecimento correlativo do patrimônio lesado. No direito brasileiro, segundo a autora, não é necessário para a configuração da obrigação de enriquecimento sem causa que haja propriamente uma saída de um valor do patrimônio do dono da coisa para entrar naquele do enriquecido, sendo o uso ou a fruição de coisa alheia exemplos típicos de situações em que não há prejuízo correspondente à vantagem obtida por um dos sujeitos.

Sobre a temática, Konder analisa que o termo empobrecimento é rejeitado porque remete imediatamente à sua concepção patrimonial, conduzindo à noção de diminuição patrimonial, o que, muitas vezes, não ocorrerá, existindo outras situações englobadas pelo instituto do enriquecimento sem causa (KONDER, 2005, p. 385).

Com os primeiros ensaios após a codificação de 2002, assim, cristalizaram-se os conceitos de enriquecimento e às custas de outrem na terminologia jurídica, sendo o acordo semântico seguido na doutrina (MICHELON JR., 2007; NANNI, 2010; SAVI, 2012; ALVIM, 2016; LINS, 2016; GUIA SILVA, 2020a) e na jurisprudência na contemporaneidade, como se infere da passagem:

\footnotetext{
Inversamente ao enriquecimento, tem-se o empobrecimento, consistente na diminuição do patrimônio ou no impedimento de seu aumento, de maneira simétrica ao enriquecimento. Esse pressuposto, ao contrário do primeiro destacado, pode vir a faltar, sem que seja descaracterizado o instituto, como nos casos, lembrado pelo autor citado acima, de serviços prestados. A dispensabilidade do empobrecimento é confirmada, inclusive, pelo art. 884 do CC, de onde se verifica que o enriquecimento suscetível de restituição é aquele operado à custa de outrem, sem qualquer referência ao empobrecimento (BRASIL, 2016).
}

Por outro lado, a construção doutrinária a respeito do terceiro requisito (nexo de causalidade) no âmbito do enriquecimento sem causa não é, pois, tão pacífica, tanto que atualmente muitos doutrinadores sequer o citam como um requisito propriamente dito (KONDER, 2005; SAVI, 2012; ALVIM, 2016; LINS, 2016; GUIA SILVA, 2020a).

Isso porque, diferentemente da complexidade que envolve o requisito na teoria da responsabilidade civil, o nexo de causalidade está para o enriquecimento sem causa como uma correlação entre o direito subjetivo violado e o enriquecimento. Basta que fique demonstrado que o enriquecimento de uma das partes ocorreu a partir do direito subjetivo de outra.

Como ensina Agostinho Alvim, “indispensável é que exista uma interdependência. Se o enriquecimento de alguém não se relacionar com o empobrecimento [em sentido amplo] de outra pessoa, nem com fato seu, nem com alguma circunstância que de qualquer modo lhe diga respeito, $[\ldots]$ o requisito do nexo terá falhado" (ALVIM, 1957, p. 23). 
Finalmente, o último requisito apontado (a ausência de justa causa), apesar da complexidade e do mérito que o engloba ${ }^{17}$, é largamente entendido na doutrina nacional como a inexistência de uma causa justificadora de atribuição patrimonial, ou seja, de um título conferido pelo ordenamento jurídico capaz de justificar o enriquecimento (ALVIM, 1957, p. 25; NORONHA, 1991, p. 69; NEGREIROS, 2002, p. 810; NANNI, 2004, p. 257; MICHELON JR., 2007, p. 208; KONDER, 2005, p. 390; SAVI, 2012, p. 61; ALVIM, 2016, p. 79). São diversas as causas aptas a justificar uma atribuição patrimonial dentro de uma determinada ordem jurídica e, assim, não há possibilidade de sistematização de todas as causas justificadoras. Entre os exemplos a serem citados, estão a legislação, o negócio jurídico e a decisão judicial, mas para o enriquecimento sem causa basta pensar que na ausência de uma dessas causas justificadoras é que se caracteriza o enriquecimento injustificado ${ }^{18}$.

É indispensável, portanto, que o enriquecimento ocorra sem uma causa legitima, quer porque falte, quer porque seja reprovada pelo ordenamento jurídico. Para se saber se houve de fato enriquecimento sem causa, caracterizando o dever de restituir, deve-se indagar se a vantagem patrimonial é atribuída, ou não, por uma causa legítima (GOMES, 1998, p. 251).

\section{A impossibilidade de uma invocação principiológica do enriquecimento sem causa no direito brasileiro}

Apesar da consolidação do enriquecimento sem causa como figura institucional do direito civil brasileiro nos idos de 2002, como evidenciado nas páginas introdutórias deste artigo, na contemporaneidade a expressão continua a ser empregada na prática forense como um princípio geral do Direito capaz de corrigir injustiças, valorar atribuições patrimoniais e dar parâmetros às mais diversas situações que batem à porta do Poder Judiciário, principalmente quando a norma traz um maior grau de discricionariedade ao intérprete-julgador.

Essa valorização ético-jurídica, contudo, é estranha ao enriquecimento sem causa que se formou instituto e não princípio geral do Direito, como passa-se a analisar neste tópico.

\footnotetext{
${ }^{17}$ Agostinho Alvim coloca que "este é o requisito que demanda maiores considerações e acerca do qual já se disse ter sido mal estudado por juristas, assim antigos como modernos (ALVIM, 1957, p. 23). No mesmo sentido, Konder pontua que "a causa já é, em si, um conceito jurídico polissêmico" e continua "boa parte da doutrina entende que a ausência de causa que justifica a actio de in rem verso é ainda um tipo peculiar. Tratar-se-ia de uma fórmula geral de reprovabilidade [...]” (KONDER, 2005, p. 389).

${ }^{18}$ Nas palavras de Noronha (1991, p. 68), "são diversas as causas justificativas de enriquecimento, com destaque para esses atos de autonomia privada que são os negócios jurídicos. Outra causa justificativa importante é lei”. Corroborando, Negreiros (2002, p. 808-809) pontua que “a lei atua como causa justificativa do enriquecimento nas hipóteses, por exemplo, de usucapião e de prescrição" e "ao lado da lei, os negócios jurídicos são considerados causa justificativa [...]. Assim, mesmo que o contrato de compra e venda, por hipótese, estabeleça um preço muito abaixo do praticado no mercado, em princípio a vantagem do comprador não será restituível, porquanto tem como causa um negócio jurídico válido celebrado entre as partes". Da mesma forma ocorre com as decisões judiciais, uma vez fixado, por exemplo, o valor indenizatório a título de danos morais, não há o que se falar em enriquecimento sem causa da parte indenizada.
} 


\subsection{As fontes históricas do enriquecimento sem causa}

Sob as perspectivas históricas, o estudo do desenvolvimento do enriquecimento sem causa remonta, em suas origens mais primitivas, as fontes romanas clássicas da condictio romana. Apesar da precisa origem dessa figura gerar certa controvérsia doutrinária, pode-se dizer que nos primeiros anos a condictio era um meio processual, cujo pressuposto era a transmissão da propriedade de uma coisa que desencadearia uma situação de re obligari, na medida que se verificava a ausência de causa para a manutenção da propriedade da coisa. Foi, então, no período romano clássico, que se operou uma extensão da condictio às diversas hipóteses em que se verificava uma atribuição patrimonial sem causa de justificação (MENEZES LEITÃO, 2005, p. 68-70), e, período pós-clássico, a condictio deixou de ser um meio processual para se constituir um termo do direito material, passando a ser empregado nas reivindicações que não se enquadravam no contrato e no delito (ZIMMERMANN, 1985, p. 5).

Com efeito, na compilação justinianeia ${ }^{19}$ a condictio aparece subdividi em categorias autônomas, quais sejam: (i) a condictio indebiti, que tinha lugar no caso de pagamento de uma obrigação inexistente, por erro desculpável; (ii) a condictio ob rem ou condictio ob causam datorum, que ocorria quando se efetuava uma prestação tendo em vista um resultado futuro que afinal não se produz; e (iii) a condictio ob turpem vel iniustam causam, que é admitida quando se deu ou prometeu algo com fins imorais ou proibidos pelo direito; (iv) a condictio sine causa, que era a hipótese residual, cabível na hipótese de não configuração das primeiras (MENEZES LEITÃO, 2005, p. 91-92) ${ }^{20}$.

Menezes Leitão (2005, p. 123-124) ensina que o conceito de iniusta causa era o fundamento de aplicação da condictio para os clássicos, este entendido como uma aquisição contra o ius, ou seja, uma aquisição não reconhecida pelo direito, inexistindo assim qualquer ligação com a equidade. Foi com os compiladores bizantinos, assim, que se introduziu no sistema das condictiones uma noção de equidade a fim de restituir as aquisições injustificadas. Nas palavras do autor "no Direito justinianeu, conforme resulta do texto de D.50.17.206, o enriquecimento sem causa tem um valor de princípio geral, embora para sancioná-lo se utilizem variados tipos de ações e meios jurídicos” (MENEZES LEITÃO, 2005, p. 127).

De igual modo, Vieira Gomes (1998, p. 55-56) pontua que foi nesse período que "o enriquecimento injustificado se transformou num princípio geral a que faz, amiúde, apelo, quer

\footnotetext{
${ }^{19}$ O Corpus Juris Civilis, o qual está divido quatro partes: Institutas, Digesto, Código e Novelas.

${ }^{20}$ Importa atentar para o fato que existe na doutrina moderna certa dificuldade em saber, ao certo, se está classificação ocorreu no período de pós-clássico ou se já havia alguma elaboração tipológica anterior, ou seja, pelos jurisprudentes clássicos (MENEZES LEITÃO, 2005, p. 9293).
} 
para explicar, quer para inverter os resultados dos textos clássicos”.

Se, por um lado, no Oriente, o enriquecimento sem causa ganhava caráter de princípio geral, por outro lado, com a queda do Império Romano no Ocidente, dava-se a decadência do Direito Romano (476 d.C.) (NANNI, 2004, p. 21). Desta forma, somente com a redescoberta dos manuscritos do Corpus Juris Civilis pela Escola dos Glosadores italiana (séculos XI e XII) que os estudos sobre o enriquecimento sem causa foram retomados.

Com as passagens do Digesto e sem maiores reflexões sobre as fontes romanas clássicas $^{21}$, os glosadores passaram a considerar o enriquecimento sem causa como verdadeiro princípio alicerçado na equidade ${ }^{22}$. Os reflexos do estudo dos glosadores foram amplamente difundidos no continente europeu no período conhecido como ius commune (direito comum) ${ }^{23}$ e, como consequência, as linhas principiológicas do Digesto ${ }^{24}$ e das glosas italianas foram introduzidas no ius proprium (direito próprio das noções) em Espanha ${ }^{25}$ e em Portugal ${ }^{26}$.

Com o advento do humanismo renascentista em França (séculos XIV e XVI), no entanto, uma nova fase na construção do direito privado se inicia. Os jurisconsultos franceses buscavam se distanciar das fontes romanas e das glosas para dar início a uma codificação privada própria. Entre as tendências da pré-codificação estava a eliminação das condictiones romanas. Para os franceses, não era necessário recorrer às fontes romanas, tampouco dar autonomia ao enriquecimento sem causa, bastando a equidade para fundar possíveis reclamos (LEITE DE CAMPOS, 1974, p. 123-125).

Por tais razões, o Code Napoléon (1804) não consagrou uma cláusula de vedação ao enriquecimento sem causa e, sob sua influência, a maioria dos países europeus continentais na

\footnotetext{
${ }^{21}$ Vieira Gomes (1998, p. 55) ensina que “a obra dos compiladores bizantinos terá uma influência determinante na reconstrução do enriquecimento sem causa operada aquando da redescoberta do direito romano. Com efeito, e até por isso que os glosadores não podiam suspeitar da existência de numerosas interpelações, para não dizer falsificações, dos textos clássicos, e também dado que os glosadores partiram da premissa de que o Corpus Juris representava uma espécie de súmula da sabedoria humana [...]”.

${ }^{22}$ Para maiores considerações, ler: MENEZES LEITÃO, 2005, p. 145 e ss; VIEIRA GOMES, 1998, p. 55 e ss.

${ }^{23} \mathrm{O}$ ius commune ou direito comum, na história, "se assenta sobre a ideia de universalidade, diretamente ligada à ideia de Império universal alimentada pelos próprios medievais". Resultante da recepção do direito romano de forma universal pelas regiões europeias continentais, a partir dos estudos da compilação de Justiniano pelos glosadores italianos, o "direito comum é constituído por um conjunto de regras decorrentes da razão, isto é, que expressam racionalidade, motivo pelo qual é compartilhado pelos povos.”. Foi assim ius commune, juntamente com o ius proprium (o direito local das regiões), que, nos séculos seguintes, pouco a pouco se transformou no sistema jurídico de cada Estado continental europeu (SALGADO, 2010, p. 255-256).

${ }^{24}$ Nas primeiras passagens do Digesto $(1,1,10,1)$ está a máxima de Ulpiano: Juris praecepta sunt haec: honeste vivere, alterum non laedere, suum cuique tribuere (Os preceitos do direito são estes: viver honestamente, não lesar outrem, dar a cada um o que é seu). Em outras passagens $(50,17,206$ e 12, 6, 14), escritas por Pompônio, também é possível perceber a presença do que no direito comum se consagrou como um princípio geral de vedação ao enriquecimento sem causa ou, como salienta Díez-Picazo, de um fundamento geral do Direito, respectivamente, jure naturae aequum est neminem cum alterius detrimento et injuria fieri locupletiorem (é justo, por direito natural, que ninguém se enriqueça em detrimento ou em prejuízo de outro) e nam hoc natura aequum est neminem cum alterius detrimento fieri locupletiorem (é por natureza justo que ninguém se enriqueça em detrimento de outro) (ZIMMERMANN, 1995, p. 403; e DIEZ-PICAZO Y PONCE DE LEON, 1988, p. 15) (Traduções livres).

${ }^{25}$ Segundo Díez-Picazo, as Siete Partidas introduziram no direito espanhol a máxima de Pompônio (50,17, 206), sob a seguinte redação "ninguno non deue enriquecerse torticeramente con daño de otro" (DIEZ-PICAZO Y PONCE DE LEON, 1988, p. 15-16). Tradução livre: “ninguém deve enriquecer-se injustamente com o prejuízo de outro'. De forma a situar o leitor, as Siete Partidas, consideradas um dos mais importantes legados do direito espanhol, são um compilado de leis espanholas, um código criado no reinado de Afonso X (complementado ao longo dos anos) e que regeu a Espanha da Idade Média à era moderna.

${ }^{26}$ Durante o reinado de Afonso III em Portugal houve a introdução das máximas romanas através dos ensinamentos dos glosadores e da introdução das Siete Partidas espanholas (MENEZES LEITÃO, 2005, p. 196).
} 
sequência do século codificaram seu direito privado. Consequentemente, Itália (1865), Portugal (1867) e Espanha (1889) não consagraram uma cláusula geral de vedação ao enriquecimento sem causa e se desvincularam das condictiones romanas ${ }^{2728}$. Por outro lado, em terras germânicas a figura do enriquecimento sem causa encontrou terreno fértil.

Zimmermann explica, nesse contexto, que, conquanto a maioria dos países europeus no decorrer do século codificaram seu direito privado com grande inspiração no Code Napoléon, nos territórios alemães se desenvolveu uma unidade intelectual promovida pela Escola de Direito Histórico de Friedrich Carl Von Savigny e pela ciência jurídica pandectista iniciada desde então, cujos estudos voltavam-se para as fontes romanas clássicas e pós-clássicas entre elas as condictiones romanas (ZIMMERMANN, 2006; ZIMMERMANN, 1985).

A ciência pandectista questionava as soluções bizantinas e do ius commune em sede de enriquecimento sem causa e, a partir disso, desenvolveu-se uma profunda crítica à concepção de que o postulado de que ninguém deveria locupletar-se à custa de outrem, como um princípio geral e indeterminado, cujas fontes estariam na acepção de equidade, pudesse ser as bases de uma ação independente de enriquecimento sem causa. Operando-se, assim, um regresso à configuração do sistema das condictiones romanas, o qual acreditava-se ser o fundamento da pretensão restituitória (MENEZES LEITÃO, 2005, p. 332-333).

Savigny, renunciando a qualquer raciocínio casuístico dominante à época, possuía como escopo investigativo identificar as diferenças, mas principalmente o elo comum das diversas condictiones romanas. Para o autor, todas as condictiones pertenciam ao mesmo sistema orgânico e possuíam como verdadeiro fundamento a restituição de tudo aquilo que um patrimônio obteve à custa da diminuição de outro patrimônio, o qual ocorreu sem causa ou em virtude de uma causa que, posteriormente, se perdeu (ZIMMERMANN, 1985, p. 8).

A argumentação de Savigny parte da concepção de que todo patrimônio tem por objeto o conjunto de relações que estão sob o poder de determinada pessoa, e todas as transformações sofridas devem ocorrer por vontade do titular do patrimônio. Ao não ocorrer essa vontade ou, ao menos, um consentimento, não haverá causa jurídica e ocorrerá o enriquecimento sem causa

\footnotetext{
${ }^{27}$ Assim como a codificação francesa, tais codificações previam a gestão de negócios e o pagamento indevido.

${ }^{28}$ A codificação francesa previa expressamente, no entanto, a gestão de negócios e o pagamento indevido, reconhecendo assim os quasecontratos pós-clássicos. O início da consagração do enriquecimento sem causa em França, em apertada síntese, deu-se somente após o abandono da concepção exegética, no período de 1870 a 1892, e aceitação da doutrina de Aubry e Rau. Mas foi em 1892, a partir do célebre arrêt Boudier, que a Corte de Cassação francesa reconheceu, de fato, a existência de uma ação autônoma de enriquecimento sem causa e introduziu de forma alargada o instituto como princípio geral no direito francês (MENEZES LEITÃO, 2005, p. 293; LEITE DE CAMPOS, 1974, p. 151-157; VIEIRA GOMES, 1998, p. 151; ALVIM, 1957, p. 17; e NANNI, 2004, p. 57). Na atualidade, em França a cláusula geral de enriquecimento sem causa só restou positivada com a reforma legislativa em 2016 (Ordonnance no 2016-131, du 10 février 2016): “Article 1303. En dehors des cas de gestion d'affaires et de paiement de l'indu, celui qui bénéficie d'un enrichissement injustifié au détriment d'autrui doit, à celui qui s'en trouve appauvri, une indemnité égale à la moindre des deux valeurs de l'enrichissement et de l'appauvrissement.". Tradução livre: Além dos casos de gestão de negócios e de pagamento indevido, aquele que se beneficia de um enriquecimento em causa à custa de outros, deve, ao empobrecido, uma indenização igual ao menor dos dois valores, enriquecimento e empobrecimento (FRANÇA. 2016).
} 
(MENEZES LEITÃO, 2005, p. 334). Savigny defendia, portanto, a necessidade de uma cláusula geral de enriquecimento sem causa, capaz de abarcar essa noção unitária de enriquecimento (ZIMMERMANN, 1985, p. 7-8) ${ }^{29}$.

Sob tal influência, nos territórios alemães à época promoveu-se o reconhecimento das condictiones romanas como verdadeiras ações de enriquecimento (Bereicherungsklagen $)^{30}$, passando o fundamento do enriquecimento sem causa de um princípio geral de equidade para a ausência de causa jurídica para o deslocamento patrimonial (MENEZES LEITÃO, 2005, p. 337). E, assim, a Segunda Comissão destinada à elaboração do Código Civil alemão (Bürgerliches Gesetzbuch-BGB), na segunda metade do século XIX, incorporou uma cláusula geral de vedação ao enriquecimento sem causa no BGB (\$812), a qual todas as condictiones poderiam se reconduzir e, por isso, aparece encabeçando o título relativo ao enriquecimento sem causa (ungerechtfertigte Bereicherung) no Código ${ }^{31}$. No entanto, a Comissão optou por substituir a expressão aus dem Vermögen eines anderen (que resulta do patrimônio de outrem), apresentada na primeira redação do artigo, pela expressão auf dessen Kosten (à sua custa), acarretando após a entrada em vigor do BGB em uma grande margem de abstração (ZIMMERMANN, 1985, p. 8; MENEZES LEITÃO, 2005, p. 349; JIUKOSKI DA SILVA; PETEFFI DA SILVA, 2020, p.240).

Zimmermann (1985, p. 11) explica que a aplicação do § 812 BGB na prática se mostrou difícil. Nos primeiros anos, não existiam diretrizes para os requisitos às suas custas (auf dessen Kosten) e sem fundamento jurídico (ohne rechtlichen Grund) contidos na cláusula geral e, por muito tempo, a literatura jurídica se mostrou incapaz de delinear uma abordagem sólida e orientativa aos tribunais, diante das múltiplas manifestações de enriquecimento.

Uma resposta clara e uniforme ao problema da abstração do enriquecimento sem causa na Alemanha (aplicada até os dias de hoje) ocorreu através dos ensaios de Walter Wilburg em 1934 e de Ernst von Caemmerer em 1954. Os autores consideravam que a acentuação de uma

\footnotetext{
${ }^{29}$ A teoria de Savigny ficou conhecida como a teoria unitária do deslocamento patrimonial e diante desta teoria, por muito tempo, os tribunais alemães entenderam que para caracterizar o dever de restituir era necessário que o enriquecimento tivesse pertencido anteriormente a outro patrimônio do empobrecido. Ou seja, que ficasse caracterizado um verdadeiro descolamento patrimonial (ZIMMERMANN, 1985, p. 12).

30 A teoria do enriquecimento sem causa desenvolvida por Savigny, no direito contemporâneo, é conhecida como teoria unitária do descolamento patrimonial (Vermögensverschiebung).

${ }^{31} \S 812$. (1) Wer durch die Leistung eines anderen oder in sonstiger Weise auf dessen Kosten etwas ohne rechtlichen Grund erlangt, ist ihm zur Herausgabe verpflichtet. Diese erpflichtung besteht auch dann, wenn der rechtliche Grund später wegfällt oder der mit einer Leistung nach dem Inhalt des Rechtsgeschäfts bezweckte Erfolg nicht eintritt (ALEMANHA, 1900). Tradução livre: Quem pela prestação de outra pessoa, ou por qualquer outro modo às suas custas, obter para si alguma coisa, sem fundamento jurídico, estará obrigado, para com este, à restituição. Esta obrigação existe ainda quando o fundamento jurídico mais tarde vier a faltar, ou quando, com uma prestação, não se realizar o resultado visado de acordo com o conteúdo do negócio. O título contém também a condictio indebiti (repetição do indevido) nos $\$ \$ 813$ e 814, a condictio ob rem (a repetição for falta do resultado visado com a prestação) no $\S 815$, a condictio ob turpem vel iniustam causam (a repetição por recepção ilícita ou reprovável da prestação) no § 817, e outras disposições estranhas à tradição pandectística, como: a restituição fundada na disposição de direitos eficaz em relação ao seu titular, a que se refere o §816 I, S.1 e II; a restituição fundada na aquisição gratuita do enriquecimento de outrem, a que se refere os §§816 I, s.2 e 822 (ZIMMERMANN, 1985, p. 8 e ss.; e LARENZ, 1958, p. 514 e ss.). Menezes Leitão ainda aponta outras disposições ao longo do BGB também acabam prevendo a restituição do locupletamento injustificado, tais como: $\S 951$ (acessão), $\$ 977$ (achado), § 2021 (restituição pelo possuidor da herança) e $\$ \S 682$ e 684 (incapacidade do gestor e assunção ilegítima da gestão de negócios) (MENEZES LEITÃO, 2005, p. 350).
} 
cláusula geral no BGB (\$812) não era apenas historicamente, mas também dogmaticamente justificada diante das diferenças das condictiones romanas e das diversas hipóteses em que o enriquecimento pode se materializar sem causa jurídica (ZIMMERMANN, 1985, p. 11).

Von Caemmerer (1966, p. 576) ensina que não se pode obter êxito no âmbito do enriquecimento sem causa a partir de uma noção unitária de enriquecimento, dado que existem diferentes hipóteses de enriquecimento em sua natureza e, assim, não se pode dar uma única resposta válida a todos os casos de enriquecimento que se materializam sem causa jurídica.

Por tal razão e observando as semelhanças e diferenças das condictiones romanas, os autores propuseram a divisão da cláusula geral de enriquecimento sem causa alemã em duas hipóteses: (i) as condictiones com base numa prestação (Leistungskondiktionen); e (ii) as condictiones não baseadas numa prestação (Nichtleistungskondiktionen).

As primeiras dizem respeito à restituição de rendimentos que ocorreram através do erro na prestação ou deveriam ser restituídos após o desaparecimento da transação causal subjacente e, por assim ser, a legislação dedica disposições especiais a cada tipo de prestação (VON CAEMMERER, 1966, p. 579). As segundas operam quando o enriquecimento não ocorrer através de uma prestação, pois o que estará em jogo é a tutela do direito alheio à custa do qual o enriquecimento se verificou. Configurando-se como elemento decisivo das obrigações de enriquecimento sem causa a expressão às suas custas (auf dessen Kosten), a qual deve ser interpretada levando em consideração o conteúdo de destinação do direito subjetivo violado (Zuweisungsgehalt) (ZIMMERMANN, 1985, p. 13) $)^{32}$.

A gênese histórica do desenvolvimento do enriquecimento sem causa demonstra assim a construção de um sólido instituto jurídico no ordenamento jurídico alemão, nas palavras de Zimmermann (1985, p. 4) de "um original e sólido sistema restituitório [...] cuja origem está nas ações striai iuris do direito romano", que se constitui fonte de obrigações ao lado dos contratos e dos delitos (VON CAEMMERER, 1966, p. 578; VON THUR, 1999, p. 7).

O BGB, tal qual ocorreu anteriormente com o Code Napoléon, passou a influenciar as novas codificações privadas nos países latinos europeus em matéria de enriquecimento sem causa. Em 1942 a nova codificação italiana disciplina no artigo 2041 uma cláusula geral de enriquecimento sem causa ${ }^{33}$ e em 1966 a nova codificação portuguesa também passa a positivar

\footnotetext{
${ }^{32}$ Zimmermann explica que entre as condictiones não baseadas em uma prestação estão a Reichgriffskondiktion (para reivindicar o enriquecimento ocorrido através do cumprimento de dívida de outrem), a Verwendungskondiktion (para reivindicar o reembolso de despesas efetuadas em coisa alheia) e a Eingriffskondiktion (para reivindicar o enriquecimento ocorrido através da intervenção não autorizada em um direto subjetivo alheio). (ZIMMERMANN, 1985, p. 12).

${ }^{33}$ Art. 1942. "Quem, sem justa causa, se enriqueceu à custa de outra pessoa é obrigado, dentro dos limites do enriquecimento, a indenizar esta última pela correlativa diminuição patrimonial. Se o enriquecimento havia por objeto uma coisa determinada, aquele que recebeu é obrigado a restituí-lo in natura, se existir ao tempo da demanda". No original: "Chi, senza una giusta causa, si è arricchito a danno di un'altra persona è tenuto, nei limiti dell'arricchimento a indennizzare quest'ultima della correlativa diminuzione patrimoniale. Qualora l'arricchimento abbia per oggetto una cosa determinata, colui che l'ha ricevuta è tenuto a restituirla in natura, se sussiste al tempo della domanda" (ITALIA,
} 
uma cláusula geral de vedação ao enriquecimento sem causa (artigo $473^{34}$ ).

Além disso, os doutrinadores portugueses passaram a reconhecer o enriquecimento sem causa enquanto fonte de obrigações e a comungar das ideias difundidas na literatura alemã sobre causa e conteúdo de destinação dos direitos absolutos (Zuweisungsgehalt) (LEITE DE CAMPOS, 1974; MENEZES LEITÃO, 2005; ANTUNES VARELA, 2005; JIUKOSKI DA SILVA; PETEFFI DA SILVA, 2020). Do mesmo modo ocorreu na doutrina espanhola, em que pese o legislador espanhol não ter positivado uma cláusula geral na modernidade, é largamente reconhecido no país o instituto a partir dos estudos doutrinários de direito comparado e das construções jurisprudenciais (DIEZ-PICAZO Y PONCE DE LEON, 1988; BASOZABAL ARRUE, 1998; CERVANTES, 2012; GIL, 2017).

Nesse contexto histórico, observa-se que os países europeus recepcionaram a figura do enriquecimento sem causa de maneira diversa na história e, na atualidade, os ordenamentos de civil law seguem basicamente o sistema casuístico francês ou o sistema de abstração de causa alemão: o primeiro caracterizado por uma regulação fragmentada e casuísta, com base em preceitos introduzidos no Código Civil, na equidade e nas raízes históricas dos quase-contrato; e o segundo determinado pelo reconhecimento do enriquecimento sem causa como fonte autônoma de obrigações, fulcrado nas condictiones romanas (GIL, 2017, p. 5-6).

\subsection{A influência germânica e o fundamento do enriquecimento em causa no direito brasileiro}

A influência das fontes germânicas, como pode ser deduzido após a leitura dos tópicos deste artigo, também chegou no direito nacional ao tratar de enriquecimento sem causa. Uma das verdadeiras inspirações da doutrina do anteprojeto que originou às disposições legislativas de 2002 foi o modelo alemão, tanto que a semelhança entre as cláusulas gerais ( $\$ 812$ do BGB e do art. 884 do CC/2002) é manifesta. Agostinho Alvim entendia que o sistema vigente no Código Civil de 1916 condenava o instituto do enriquecimento sem causa, já os sistemas modernos, como são o Código de Obrigações suíço e o BGB, procuram coibir o enriquecimento sem causa, onde quer que se apresente, como ocorria tradicionalmente no Direito Romano. Desta forma, enfatiza o autor, “ao sistema moderno pertencem, também, o nosso Anteprojeto

1942). No entanto, a influência francesa permaneceu no direito italiano, tanto que, como dispõe Gallo, a acepção doutrinária parte do pressuposto de que para caracterizar o dever de restituir, segundo a cláusula geral, exige-se uma efetiva diminuição patrimonial. Enquanto na Alemanha, para impor a obrigação de restituição, não há necessidade da prova da diminuição patrimonial, na Itália, onde não só é essencial a prova de dano em sentido próprio, é imposto a obrigação de restituição apenas a medida de menor valor entre o enriquecimento e a respectiva diminuição patrimonial (GALLO, 1990, p. 384-385).

${ }^{34}$ Art. 473. (I) Aquele que, sem causa justificativa, enriquecer à custa de outrem é obrigado a restituir aquilo com que injustamente se locupletou; e (II) A obrigação de restituir, por enriquecimento sem causa, tem de modo especial por objecto o que for indevidamente recebido, ou o que for recebido por virtude de uma causa que deixou de existir ou em vista de um efeito que não se verificou. (PORTUGAL, 1967). 
de Código de Obrigações" (ALVIM, 1957, p. 06).

A própria redação da cláusula geral brasileira e das demais disposições restituitórias presentes na codificação dão margem à classificação alemã do enriquecimento sem causa. Aqui é fundamental as observações de Menezes Leitão (2004, p. 28) que, ao trazer uma resenha acerca das teorias sobre o instituto do enriquecimento sem causa ao Brasil, na II Jornada de Direito Civil, interpretou as disposições legislativas nesse sentido. Para o doutrinador português, "a cláusula do enriquecimento sem causa, constante do art. 884 do Código Civil brasileiro, [...], não permitindo o tratamento dogmático unitário do enriquecimento sem causa uma adequada subsunção aos casos concretos. Haverá de estabelecer uma tipologia de categorias que efetue, pela integração do caso em uma delas, a referida subsunção" e assim defende a divisão do instituto tal qual ocorre em Portugal e na Alemanha.

Além disso, a doutrina nacional ainda nos idos do Código de 1916 passou a empregar a locução à custa de outrem a partir da acepção de conteúdo de destinação e a entender pela noção de causa apta a justificar uma atribuição patrimonial dentro de uma determinada ordem jurídica (ALVIM, 1957; NORONHA, 1991; NEGREIROS, 2002; NANNI, 2004; MICHELON JR., 2007; KONDER, 2005; SAVI, 2012; ALVIM, 2016).

Em outras palavras, no direito brasileiro valorou-se a abstração da causa e o instituto enquanto fonte de obrigações e assim não se pode defender que o fundamento desse instituto é a equidade, a justiça ou a moral ${ }^{35}$ - estes resquícios das interpretações bizantinas e das glosas do ius commune -, mas sim a causa de atribuição (iniusta causa) como no direito alemão e nas raízes romanas clássicas.

Como salienta Noronha (1991, p. 52), a justificativa apresentada nos primeiros anos para o reconhecimento do enriquecimento sem causa no Brasil fundada nos velhos brocados romanos não é o verdadeiro fundamento do enriquecimento sem causa, o qual está na teoria da destinação ou atribuição jurídica dos bens (Zuweisungsgehalt). Isso porque, em geral, os sistemas jurídicos, ao atribuir às pessoas os direitos absolutos, oponíveis erga omnes, está reservado a elas, e só a elas, o aproveitamento econômico dos bens (materiais ou imateriais), e ao instituto do enriquecimento sem causa cabe corrigir as riquezas retirando o enriquecimento do patrimônio enriquecido sem a devida atribuição e restituindo a quem de direito pertence.

O enriquecimento sem causa é, pois, ramo do direito das obrigações ao lado das obrigações negociais e de responsabilidade civil e se estiver fundado nas noções de justiça e equidade extraídas das interpretações romanas pós-clássicas, não é diferente dos outros dois

\footnotetext{
${ }^{35}$ Utilizando-se das fontes francesas, Agostinho Alvim defendia que entre os fundamentos do enriquecimento sem causa estavam a moral, a justiça e a equidade (ALVM, 1957, p. 11).
} 
ramos citados (NORONHA, 1991, p. 57). Significa dizer que as fontes obrigacionais possuem como elo comum a mantença do equilíbrio natural das riquezas, mas nasceram como soluções técnicas no direito romano, tanto que não se fala de um princípio geral de responsabilidade civil ou dos contratos como critérios de equidade ou razoabilidade capazes de corrigir injustiças.

Zimmermann, nesse contexto, ensina que as fontes obrigações são maneiras de implementar a máxima de Ulpiano contida nas primeiras passagens do Digesto $(1,1,10,1)$ : Juris praecepta sunt haec: honeste vivere, alterum non laedere, suum cuique tribuere (Os preceitos do direito são estes: viver honestamente, não lesar outrem, dar a cada um o que é seu), mas não justifica tratar enriquecimento sem causa como um princípio jurídico fulcrado na equidade (ZIMMERMANN, 1995, p. 404; ZIMMERMANN, 1985, p. 4).

De igual modo Díez-Picazo pontua que o termo enriquecimento sem causa indica a existência de uma figura institucional de carácter concreto, delineado por requisitos e configurado pela produção de determinados efeitos, e, por assim ser, qualquer valoração moral é estranha ao instituto. Sem falar que qualquer generalização nunca foi uma boa experiência metodológica para o Direito (DIEZ-PICAZO Y PONCE DE LEON, 1988, p. 37 e 44).

O enriquecimento sem causa é com todas as suas potencialidades instituto jurídico e não uma carta aberta ao operador do direito capaz de corrigir injustiças ou valorar atribuições jurídicas. Como salienta Guia Silva (2020b), "não incumbe ao regramento do enriquecimento sem causa, por exemplo, definir a ocorrência da frustração do programa contratual por culpa do devedor inadimplente, tampouco a abusividade de cláusulas insertar em contratos de consumo, mas sim disciplinar os efeitos da ausência superveniente da causa de atribuição”.

Nesse mesmo contexto, Câmara Alvarez disserta que quando se paga um preço muito inferior ao valor venal se está enriquecendo injustamente, mas existe uma causa de atribuição (contrato) e não se pode valer de um princípio de vedação ao enriquecimento sem causa para buscar uma restituição. O Direito só persegue esses casos, ainda que injustos, quando o contrato foi celebrado, por exemplo, sem que uma das partes goze de uma liberdade mínima exigida, mas não por um critério de justiça comutativa, até porque inexiste tal princípio no mundo das relações econômicas (CÂMARA ALVEZ, 1988, p. 153). O mesmo ocorre no caso da prescrição e da usucapião, as quais até podem ser valoradas muitas vezes como injustas, mas não são ilegítimas. Sem falar que enriquecimento sem causa não é, em hipótese alguma, critério quantitativo de danos extrapatrimoniais, tampouco valorativo de danos materiais.

Sob tais perspectivas, assim, percebe-se que a segurança jurídica postula opor um tratamento sistemático do enriquecimento sem causa no direito brasileiro. Não se pode desconsiderar seu título de instituto jurídico por um caráter principiológico, alicerçado em 
vagas noções de justiça e equidade. Invocar indiscriminadamente um princípio de vedação ao enriquecimento sem causa como "válvula de escape" ou "panaceia para todos os problemas" não é, inclusive, a solução desenhada no sistema jurídico brasileiro que delimitou comandos normativos próprios ao tratar das causas de atribuição patrimonial e de possíveis lacunas.

\section{Conclusão}

Do exame proposto, conclui-se que o presente estudo logrou êxito ao responder à pergunta de pesquisa proposta. A partir da reconstrução histórica do enriquecimento sem causa, de suas fontes romanas, medievais e modernas até sua consolidação contemporânea no Brasil, deixa-se claro que tal figura é fonte de obrigações, ao lado das obrigações negociais e de responsabilidade civil, e um importante instituto do Direito Civil, cujo verdadeiro fundamento está na teoria da destinação ou atribuição jurídica dos bens (Zuweisungsgehalt), e não princípio implícito à ordem jurídica baseado nas noções mais remotas de justiça e equidade.

Outrossim, demonstrou-se a necessidade latente de um tratamento uniforme do instituto do enriquecimento sem causa em terras brasileiras, com a consequente eliminação de seu enquadramento principiológico. Tal conotação nasceu diante da necessária reação doutrinária e jurisprudencial à lacuna legislativa de 1916, mas que está superada desde a promulgação do Código Civil de 2002, e, consequentemente, sua constante invocação só está contribuindo para interpretações errôneas e vazias do instituto.

Qualquer uso do enriquecimento sem causa com uma conotação principiológica capaz de corrigir injustiças e dar parâmetros às mais diversas situações (ainda que patrimoniais) acaba por contribuir para a desnaturalização do instituto na contemporaneidade, que, com melhor ou pior sorte, tem seus requisitos, limites e potencialidades definidos no direito das obrigações. Como corolário lógico, para o exercício da pretensão restituitória é necessário invocar e comprovar todos os seus requisitos - enriquecimento, às custas de outrem e ausência de causa de atribuição -, por vezes esquecidos na prática forense.

De mais a mais, não se deixa de atentar ao fato que não cabe ao instituto do enriquecimento sem causa corrigir injustiças ou valorar atribuições patrimoniais - ainda que no campo das demais fontes de obrigações (quantificação de danos e critérios negocias), quando a norma traz maior discricionariedade ao intérprete-julgador ou em casos de evidente lacuna legislativa -, a essas hipóteses o próprio ordenamento jurídico nacional cuidou de resguardar tecnicamente. Ao instituto cabe corrigir as riquezas na ausência de uma causa justificadora eleita pela ordem jurídica, seja uma norma, um negócio jurídico ou uma decisão judicial. 
Por fim, pode-se dizer que o presente artigo é uma contribuição para o debate acadêmico sobre o enriquecimento sem causa, ressaltando o histórico e a importância do instituto para o ordenamento jurídico nacional. A expectativa é ter norte para tão rica temática que envolve o instituto do enriquecimento sem causa, que merece a sua devida atenção como fonte do Direito Obrigacional, ao lado das obrigações de responsabilidade civil e negocias.

\section{Referências}

ANTUNES VARELA, João de Matos. Das obrigações em geral. v. I, 10. ed. Coimbra: Almedina, 2005.

ALEMANHA. Bürgerliches Gesetzbuch. Código Civil alemão de 1900. Disponível em: https://www.gesetze-im-internet.de/englisch_bgb/. Acesso em: 19 set. 2019.

ALVIM, Agostinho de Arruda. Do enriquecimento sem causa. Revista dos tribunais, v. 259. São Paulo, 1957.

ALVIM, Rafael da Silva. Contornos conceituais do princípio de vedação ao enriquecimento sem causa no direito brasileiro. Revista Fórum de Direito Civil, Belo Horizonte, ano 5, n.11, p. 55-84, jan./abr., 2016.

BASOZABAL ARRUE, Xabier. Enriquecimiento Injustificado por Intromision en Derecho Ajeno. Madri: Editorial Civitas, 1998.

BEVILÁQUA, Clóvis. Direito das obrigações. Ed. Hist. Rio de Janeiro: Editora Rio, 1977.

BRASIL. Conselho da Justiça Federal. I Jornada de Direito Civil, dias 12 e 13 de setembro de 2002. Disponível em: http://www.cjf.jus.br/cjf/CEJ-

Coedi/jornadascej/Jornada\%20de\%20Direito\%20Civil\%201.pdf/view. Acesso em 14 nov. 2019.

BRASIL, Superior Tribunal de Justiça (4. Turma). REsp 1497769/RN. Relator: Ministro Luís Felipe Salomão. Brasília, 05 de maio de 2016.

BRASIL, Superior Tribunal de Justiça (3. Turma). REsp. 11025/SP. Relator: Min. Waldemar Zveiter. Brasília, 29 janeiro de 1991.

CAMARA ALVAREZ, Manuel de la. Enriquecimiento injusto y sin causa. In: DÍEZ-PICAZO Y PONCE DE LEON, Luis; CAMARA ALVAREZ, Manuel de la. Dos estudios sobre el enriquecimiento sin causa. Madri: Editorial Civitas, 1988.

CERVANTES, Carles Vendrell. La acción de enriquecimiento injustificado por intromisión en los derechos al honor, a la intimidad y a la propia imagen. Anuário de Derecho Civil. Tomo LXV, fasc. III, jan.-mar., pp. 1108-1244, Madrid: BOE, 2012.

DIEZ-PICAZO Y PONCE DE LEON, Luis. La doctrina del enriquecimiento injustificado. In: DÍEZ-PICAZO Y PONCE DE LEON, Luis; CAMARA ALVAREZ, Manuel de la. Dos 
estudios sobre el enriquecimiento sin causa. Madri: Editorial Civitas, 1988.

FERREIRA, José G. do Valle. Enriquecimento sem causa. Belo Horizonte: Imprensa Oficial, 1949.

FRANÇA. Code Civil. Código Civil francês. Ordonnance n. 2016-131, de 10 fevereiro de 2016. Disponível em: www.legifrance.gouv.fr/affichTexte.do?cidTexte= JORFTEXT000032004939\&categorieLien=id. Acesso em: 15 set. 2019.

GALLO, Paolo. L’arrichimento senza causa. Padova: Universitá di Trento, 1990.

GIL, Laura Zumaquero. El enriquecimiento injustificado em el Derecho Privado Europeo. Revista para el Análises del Derecho. Barcelona, abr., 2017.

GOMES, Orlando. Obrigações. 12. ed. Rio de Janeiro: Editora Forense, 1998.

GUIA SILVA, Rodrigo da. Cláusula geral de restituição do enriquecimento sem causa. Revista de Direito Privado, v. 103, p. 191- 237, jan./fev. 2020a.

GUIA SILVA, Rodrigo da. Enriquecimento sem causa no contexto da covid-19: armadilhas e potencialidades do instituto realçadas pela pandemia. Migalhas, $2020 \mathrm{~b}$.

GUIA SILVA, Rodrigo da. Fontes das Obrigações e regimes jurídicos obrigacionais gerais: em busca do papel da vedação ao Enriquecimento Sem Causa no Direito Civil Contemporâneo. Revista da Faculdade de Direito da Uerj. Rio de Janeiro, n. 36, dez. 2019a.

GUIA SILVA, Rodrigo da. Prazo prescricional da pretensão de repetição de indébito: um diálogo necessário entre pagamento indevido e enriquecimento sem causa. Civilistica.com. Rio de Janeiro, a. 8. n. 2. 2019b.

JIUKOSKI DA SILVA; PETEFFI DA SILVA. O tratamento dado ao lucro da intervenção no ordenamento jurídico português. In: RUZYK, Carlos Eduardo Pianovski; ROSENVALD, Nelson (coord.). Novas fronteiras da Responsabilidade Civil: direito comparado. Rio de Janeiro: Editora Foco, p. 237-254, 2020.

ITÁLIA. Codice civile, de 16 março 1942. Código Civil italiano. Disponível em: https://www.altalex.com/documents/news/2013/04/11/dell-arricchimento-senza-causa. Acesso em: 15 set. 2019.

KONDER, Carlos Nelson. Enriquecimento sem causa e pagamento indevido. In: TEPEDINO, Gustavo (Org.). Obrigações: Estudos na perspectiva civil-constitucional. Rio de Janeiro: Renovar, pp. 369-398, 2005.

KROETZ, Maria Candida do Amaral. Enriquecimento sem causa no direito civil brasileiro contemporâneo e recomposição patrimonial. Tese de doutoramento. Curitiba: UFPR, 2005.

LARENZ, Karl. Derecho de Obligaciones. Tomo II. Trad. Jaime Santos Briz. Madrid: Editorial Revista de Derecho Privado, 1958. 
LEITE DE CAMPOS, Diego José Paredes. A subsidiariedade da obrigação de restituir o enriquecimento. Coimbra: Almedina, 1974.

LINS, Thiago. O lucro da intervenção e o direito à imagem. Rio de Janeiro: Lumen Juris, 2016.

MENEZES LEITÃO, Luís Manuel Teles de. O enriquecimento sem causa no direito civil: estudo dogmático sobre a viabilidade da configuração unitária do instituto face à contraposição entre as diferentes categorias de enriquecimento sem causa. Coimbra: Almedina, 2005.

MENEZES LEITÃO, Luís Manuel Teles de.. O enriquecimento sem causa no novo Código Civil brasileiro. Revista CEJ. Brasília, n. 25, p. 24-33, abr.jun. 2004.

MICHELON JR., Claudio. Direito restituitório: enriquecimento sem causa, pagamento indevido, gestão de negócios. São Paulo: Revista dos Tribunais, 2007.

NANNI, Giovanni Ettore. Enriquecimento sem causa. São Paulo: Saraiva, 2004.

NEGREIROS, Teresa. Enriquecimento sem causa: aspectos de sua aplicação no Brasil como um princípio geral de direito. Revista da Ordem dos Advogados. Ano 55. Ordem dos Advogados Portugueses, pp. 757-845, 2002.

NONATO, Orosimbo. Curso de obrigações. 2. ed. Rio de Janeiro: Forense, 1960.

NORONHA, Fernando. Enriquecimento sem causa. Revista de Direito Civil, Imobiliário, Agrário e Empresarial, São Paulo: RT, v. 56, p. 51-78, abr./jun., 1991.

PAES, Pedro. Introdução ao estudo do enriquecimento sem causa. São Paulo: [s.n], 1975.

PONTES DE MIRANDA, Francisco Cavalcanti. Tratado de Direito Privado. Parte Especial. Tomo XXVI. 2 ed. Rio de Janeiro: Borsoi, 1959.

PORTUGAL. Decreto Lei n. 47344, de 25 de novembro de 1966. Código Civil português. Disponível em: http://www.pgdlisboa.pt/leis/lei_mostra_articulado.php?nid=775 \&tabela=leis. Acesso em: 21 set. 2019.

RODRIGUES, Silvio. Direito Civil: parte geral das obrigações. 24. ed. São Paulo: Saraiva, 1996.

SALGADO, Karine. O Direito tardo medieval: entre o Ius Commune e o Ius Proprium. Revista da Faculdade de Direito UFMG, Belo Horizonte, n. 56, p. 243-264, jan./jun. 2010.

SAVI, Sérgio. Responsabilidade civil e enriquecimento sem causa: o lucro da intervenção. São Paulo: Atlas, 2012.

SETE partidas. In: Biblioteca Digital Mundial. Washington: Library of Congress, 2017. Disponível em: https://www.wdl.org/pt/item/10642/. Acesso em: 15 set. 2019.

VIEIRA GOMES, Júlio Manuel. O conceito de enriquecimento, o enriquecimento forçado 
e os vários paradigmas do enriquecimento sem causa. Porto: UCP, 1998.

VON CAEMMERER, Ernst. Problèmes fondamentaux de l'enrichissement sans cause. In: Revue internationale de droit compare, v. 18, n. 3, p. 573-592, Juillet/Septembre, 1966.

VON THUR, Andreas. Tratado de las obligaciones. Tradução de W. Roces. Madrid: Ed. Reus, 1999.

ZIMMERMANN, Reinhard. A road through the enrichment-forest? Experiences with a general enrichment action. Institute of Foreign and Comparative Law, v. 18, p. 1-20, mar. 1985.

ZIMMERMANN, Reinhard. The german civil code and the development of private law in Germany. Oxford U Comparative $\mathbf{L}$ Forum 1, 2006. Disponível em: https://ouclf.law.ox.ac.uk/the-german-civil-code-and-the-development-of-private-law-ingermany/. Acesso em: 15 set. 2019.

ZIMMERMANN, Reinhard. Unjustified enrichment: the modern civilian approach. Oxford Journal of Legal Studies, Oxford University Press, v. 15, n. 3, p. 403-429, 1995. 